\title{
Assimilation of terrigenous organic matter via bacterial biomass as a food source for a brackish clam,
}

\section{Corbicula japonica (Mollusca: Bivalva)}

\author{
ToshiroYamanaka $^{\mathrm{a} *}$, Chitoshi Mizota ${ }^{\mathrm{b}}$, Yonosuke Maki ${ }^{\mathrm{c}}$, Masatoshi Matsumasa ${ }^{\mathrm{d}}$ \\ ${ }^{a}$ Present address: Graduate School of Natural Science and Technology, Okayama University, 1-1, Naka \\ 3-chome, Tsushima, Okayama, 700-8530, Japan \\ ${ }^{\mathrm{b}}$ Faculty of Agriculture, Iwate University, Morioka 020-8550, Japan \\ ${ }^{c}$ Faculty of Humanities and Social Sciences, Iwate University, Ueda 3-18-34, Morioka 020-8550, Japan \\ ${ }^{\mathrm{d}}$ Department of Biology, Iwate Medical University, Nishitokuta 2-1-1, Yahaba-cho Iwate 028-3694, Japan \\ * corresponding author: T. Yamanaka \\ e-mail: toshiroy@cc.okayama-u.ac.jp
}

\section{ABSTRACT}

Corbicula japonica collected from the Kitakami River estuary, northeastern Japan, showed lower $\delta^{34} \mathrm{~S}$ values in soft body parts $(+1.7$ to $+11.0 \%)$ than the ambient seawater sulfate-sulfur $(+21 \%)$, and this value gradually decreased at successive sites up to $15.8 \mathrm{~km}$ upstream from the river mouth. Previous study using carbon and nitrogen isotopes suggests that the bivalve nonselectively assimilates particulate organic matter of marine and terrestrial origin by filter feeding. This pattern in $\delta^{34} \mathrm{~S}$ values may indicate a considerable contribution of a food source derived from terrigenous organic matter, which has low $\delta^{34} \mathrm{~S}$ values close to $0 \%$, and the bivalve has been reported to have cellulase and hemicellulase activities. Unique fatty acids (iso 17:0 and anteiso 17:0 acids), 
both characteristic of sulfate-reducing bacteria, were observed in the salt-free, soft-body parts of the bivalve. The concentration of monounsaturated fatty acids, possibly derived from bacteria, was also high. Trace amounts of a polyunsaturated fatty acid (20:5 13$)$ specific to dinoflagellates were detected. In Corbicula habitats, reductive sandy layers with ample sulfides that were sporadically intercalated into the oxidative sandy sediment were often observed. The stable isotopic signatures of sediment sulfides (acid-volatile sulfide) and associated pore-water sulfates were -8.9 to $+8.6 \%$ and +22.4 to $+26.3 \%$, respectively, indicating the existence of bacterial sulfate-reducing activity and thiobios biomass. These isotopic signatures of the sediment, with the fatty acid composition of the bivalve, confirm the importance of a food source derived from bacteria belonging to the thiobios in the substrate sediments via pedal feeding, rather than direct digestion of terrigenous organic matter, in this estuarine ecosystem.

Keywords:

Corbicula japonica

Food resources

Fatty acids

Biomarkers

Sulfur isotopes

Kitakami River, Northeastern Japan

\section{Introduction}

The bivalve Corbicula japonica is one of the most common brackish-water infauna in Japan, although its population is decreasing due to the loss of oligo- and mesohaline soft-bottom habitats. This nonselective 
filter-feeding species inhabits sandy sediments with ample oxygen supply and feeds on phytoplankton in mesohaline lagoons (Nakamura et al., 1988). Algae, including diatoms and cyanobacteria, are considered the possible major food source for $C$. japonica (Yamamuro, 1995). However, this interpretation awaits further empirical tests because the food source of this nonselective filter feeder may change according to the environmental conditions of habitats (e.g., Doi et al., 2005; Kasai and Nakatsu, 2005). For example, diatoms would be the major food source for $C$. japonica in diatom-rich lakes and lagoons, but densities of diatoms are usually quite low in rivers (McLusky, 1989). Although direct evidence is lacking, cellulase and hemicellulase activities of the bivalve have been reported (Sakamoto and Toyohara, 2009a), and in particular, endogenous cellulase and xylanase genes have been identified (Sakamoto and Toyohara, 2009b), which may suggest the active digestion of terrigenous organic matter, especially vascular plant detritus.

Analyses of stable isotopic ratios of carbon, nitrogen, and sulfur have been proven to be useful tools for elucidating possible food sources in shallow marine environments (e.g., Kharlamenko et al., 2001). Food sources derived from the biomass of sulfate-reducing bacteria (SRB) are being increasingly recognized as important for infauna in many tidal areas. SRB play an important role in the mineralization of organic matter in anoxic sediment under marine-brackish conditions, while hydrogen sulfide occurs as a result of sulfate reduction by SRB. Sulfide occurrence has been expected to support thioautotrophic production and chemosynthesis-based organisms such as solemyid and thyasirid clams (McLeod and Wing, 2007). This biotope, almost restricted to anoxic and sulfide rich conditions, has been defined as the "thiobios." The bacterial biomass belonging to the thiobios is characterized by lower $\delta^{34} \mathrm{~S}$ values (ca. $-20 \%$ ) than those from common marine organisms, which rely on primary production from plankton (>+15\%) (see Yamanaka et al., 2000). Therefore, when a low $\delta^{34} \mathrm{~S}$ value is observed for an organism inhabiting marine-brackish environments, this suggests a positive incorporation of the sulfur nutrition derived from the microbial sulfide formed by the reduction of ambient 
seawater sulfate $\left(\delta^{34} \mathrm{~S}=+21 \%\right.$; Rees et al., 1978). In the case of lacustrine and fluvial conditions, it means that sufficient sulfate is not available for sulfate reduction by SRB, and $\delta^{34} \mathrm{~S}$ values of mollusks range from 0 to $6 \%$ (e.g., Yamanaka et al., 2000) because inorganic sulfur nutrition for primary producers is provided as a result of the weathering of continental rocks, which have low $\delta^{34} \mathrm{~S}$ values close to $0 \%$.

Fatty acids, which are metabolic products in animal bodies, have also been used recently as tracers in estuarine food webs. For example, Ruditapes philippinarum contained a large amount of branched fatty acids (iso 17:0 and anteiso 17:0 acids), which are unique to sulfate-reducing bacteria (Findlay et al., 1990; Kharlamenko et al., 2001). Similar figures have been documented for two epifaunal gastropods, Terebralia sulcata and Cerithideopsilla cingulata, from an intertidal flat associated with mangrove forest in Okinawa, Japan (Meziane and Tsuchiya, 2000; Meziane et al., 2002). Such occurrences of unique fatty acids in animal bodies, in addition to low values of $\delta^{34} \mathrm{~S}$, provide further evidence for their uses of bacterial biomass. Similarly, the indirect assimilation of terrigenous organic matter via heterotrophic bacteria by some benthic marine macroinvertebrates inhabiting the inner reaches of some fjords has been demonstrated (McLeod and Wing, 2009).

In this study, we verified the major food source for $C$. japonica inhabiting an estuarine ecosystem in the Kitakami River, northeastern Japan, using stable sulfur isotope and fatty acid analyses. The food habitat of $C$. japonica inhabiting the area has already been studied by Doi et al. (2005) using carbon and nitrogen stable isotopes. They suggested that $C$. japonica inhabiting the upper stream show relatively higher contributions of terrigenous-origin food (vascular plant detritus derived as particulate organic matter (POM), but no assimilation of adjacent marsh plants Phragmites australis and Typha latifolia) than in communities close to the river mouth. However, they did not interpret the way in which $C$. japonica assimilates vascular plant detritus in spite of its refractory nature against biodegradation. Our study is also expected to provide some information for verifying 
whether $C$. japonica assimilates vascular plant detritus directly using cellulase and hemicellulase activity or indirectly via heterotrophic bacteria biomass. In contrast to knowledge about semi-closed ecosystems such as lakes and lagoons, our results strongly indicate the importance of food sources derived from the microbial biomass of the thiobios for this abundant filter-feeder in an open estuarine ecosystem.

\section{Materials and methods}

\subsection{Study area}

The Kitakami River estuary is located in the northeast of Honshu Island, Japan (38 $30^{\prime}-34^{\prime}$ N, $141^{\circ} 18^{\prime}-28^{\prime}$ E, Fig. 1 (put figure 1 here)). Samples examined in this study were collected from the stations shown in Fig. 1. Stations 4 and 7 were intertidal plots, while the other stations were subtidal. St. 4 had a relatively large, open intertidal area that was not shaded by marsh plants, while almost all the other intertidal banks were covered by salt marshes consisting mainly of $P$. australis and having only narrow, bare areas at their edges. The light intensity on the bottom sediment of the salt marsh near St. 4 (mean during July-Oct. 2002 was ca. 10,000 lx) was much lower than those of the adjacent, open flats, and the chlorophyll concentration was also much lower in the salt marsh (mean ca. $1.0 \mu \mathrm{g} \mathrm{cm}^{-2}$ ) than on the open mud flat (mean ca. $2.4 \mu \mathrm{g} \mathrm{cm}^{-2}$ ) (Kudo et al., personal communication). The salinity at each station changes greatly depending on the freshwater inflow into the estuary and tidal cycles (e.g., during 1999, the range of salinities in the surface water at St. 4 was ca. 0-30PSU).

\subsection{Sampling}


Corbicula japonica was collected with a dredge using a boat at stations 1, 4, 5, 7, 8, and 9 during the diurnal high tide period on 10 Aug. 2001. The distance from station 1 to station 9 is $15.8 \mathrm{~km}$. At the intertidal stations, the bivalves were also sampled by hand during the diurnal low tides on 15 Dec. 2001 (only at St. 4) and 15 June 2003 (at St. 4 and St. 7). Surface water (2 L) was sampled in a plastic bottle at St. 4 (the density of $C$. japonica was highest at this station) on 7 Sept., 23 Nov., and 15 Dec. 2001, and 11 Feb. 2004. Additional water samples were also collected from St. 2, St. 5, and St. 6 on 15 Dec. 2001, and from St. 10 (freshwater sample) on 21 Apr. 2001. Sediment samples (depth $<3 \mathrm{~cm}$ ) were collected using a medicine spoon from St. 4 on 17 May, 31 May, 25 Sept., 24 Oct., and 2 Nov. 2003 and on 11 Feb. 2004, and from St. 7 on 15 June 2003. On 17 and 31 May, 15 June 2003, and $11 \mathrm{Feb} .2004$, the black reductive sediments just beneath the thin brown sand layer $(<1 \mathrm{~cm}$ in thickness) were sampled separately from the oxidative brown sediments. All sediment samples were transferred to the laboratory under cool conditions $\left(\mathrm{ca} .0^{\circ} \mathrm{C}\right.$ ). Pore water from the sand sediments was extracted using a plastic syringe within $4 \mathrm{~h}$ of sampling in the field. Particle-size analysis of the substratum sand sample from St. 4 was performed by common gravity sedimentation and size-fractionation by wet sieving.

\subsection{Sulfur isotope composition}

The preparation and procedures for the analyses of sulfur content and isotopic ratios of animal, water, and sediment samples were the same as those described elsewhere (Mizota et al., 1999; Yamanaka et al., 1999, 2000, 2003; Yamanaka and Mizota, 2001). Sediment samples were dialyzed against distilled water to eliminate pore-water sulfates. The total sulfides were converted into sulfate by heating with hot hydrogen peroxide solution. Acid volatile sulfide (AVS) was liberated by anaerobic acidification in $1 \mathrm{~N} \mathrm{HCl}$ of sediments during active distillation (pure nitrogen gas); the liberated $\mathrm{H}_{2} \mathrm{~S}$ was collected in traps containing cadmium acetate 
solution $(2.5 \%)$ and then the sulfide was precipitated as CdS. The yellow CdS precipitate was oxidized with a few drops of hydrogen peroxide solution (34.5\%). These resulting sulfates were recovered as $\mathrm{BaSO}_{4}$ by adding $\mathrm{BaCl}_{2}$ solution. Pore-water sulfate and river water sulfate were also recovered as $\mathrm{BaSO}_{4}$ after the removal of major cations using cation exchange resin. The $\mathrm{BaSO}_{4}$ sample was then mixed with excess $\mathrm{V}_{2} \mathrm{O}_{5}-\mathrm{SiO}_{2}$ and finally converted into $\mathrm{SO}_{2}$ using a vacuum line, as described by Yanagisawa and Sakai (1983). The evolved $\mathrm{SO}_{2}$ sample was used to measure ${ }^{34} \mathrm{~S} /{ }^{32} \mathrm{~S}$ ratios with a VG SIRA 10 mass spectrometer.

\subsection{Fatty acid composition}

We generally followed the procedures described by Harvey et al. (1987). Freeze-dried samples of the salt-free, soft-body parts of $C$. japonica collected from St. 4 and St. 7 were homogenized by fine crushing. Lipids in the sample materials (ca. $20 \mathrm{mg}$ ) were extracted three times, with $20 \mathrm{ml}$ of a chloroform-methanol mixture (3:1 by volume) each time via sonic agitation (Vibra cell model 130; Sonics \& Materials Inc., Newtown, CT, USA). The extracts were combined and concentrated with a rotary evaporator. The total lipids were transferred into a 5-ml ampule and dried with a gentle stream of dry $\mathrm{N}_{2}$ at room temperature. The dried lipid was subject to saponification using $0.5 \mathrm{ml}$ of methanolic $0.5 \mathrm{M} \mathrm{KOH}$ plus $0.1 \mathrm{ml} \mathrm{M}-\mathrm{Q}$ water and heated $\left(100^{\circ} \mathrm{C}, 2 \mathrm{~h}\right)$ after purging the headspace with $\mathrm{N}_{2}$ and sealing the ampule head. Samples were cooled down, and water was added. The neutral and basic fractions were removed by partitioning into a hexane:diethyl ether mixture (9:1 by volume). The remaining extract was acidified to $\mathrm{pH} \leq 2$ with conc. $\mathrm{HCl}$, and the acidic fraction, which represents entire fatty acids (FAs), was partitioned in a similar manner. The free FAs were then transformed into methyl derivative by treatment with $\mathrm{BF}_{3}$-methanol reagent. The resulting esters (FAMEs) were purified by column chromatography. A GC-17A gas chromatograph and GCMS-QP2000A gas 
chromatograph mass spectrometer (Shimadzu, Kyoto, Japan) were used for the identification and quantitative estimation of fatty acid composition. Separation of FAMEs was performed on fused silica capillary columns (nonpolar type: TC-1, $30 \mathrm{~m} \times 0.25 \mathrm{~mm}$ inner diameter, $0.25 \mu \mathrm{m}$ film thickness, GL Sciences, Tokyo, Japan; polar type: RTX-2330, $30 \mathrm{~m} \times 0.25 \mathrm{~mm}$ inner diameter, $0.20 \mu \mathrm{m}$ film thickness, Restek Co., Bellefonte, PA, USA). Helium was used as a carrier gas, and the split ratio was 1:50. Individual peaks of the FAMEs were identified by comparing the retention times and mass spectra with those of authentic compounds. All fatty acid analyses were performed in duplicate. The standard deviation was less than $\pm 5 \%$ of the mean during the present study. For simplicity, some fatty acids present in very small amounts are not listed in Table 3. Nevertheless, all fatty acids detected are included in the sums and listed for the different fatty acid categories: saturated, monoenoic, branched, and polyunsaturated fatty acids (PUFAs).

The fatty acid composition was characterized by chain length. Carbon number is followed by a colon and the number of double bonds. Location of the double bond is specified from the methyl end ( $\omega$-). The prefixes ' $\mathrm{i}$,' 'ai,' and 'br' refer to iso, anteiso, and unidentified position methyl-branching, respectively. The suffixes 'c' and '?' refer to cis isomer and unidentified double bond positions, respectively.

\section{Results}

\subsection{Sulfur isotope composition}

The $\delta^{34} \mathrm{~S}$ values of six samples of $C$. japonica taken on 10 Aug. 2001 showed a systematic decrease from $+9.1 \%$ at the river mouth to $+1.7 \%$ at the most upstream station near the barrage (Table 1 ; see also Fig. 1(put

Table 1 here)). The values on different dates from St. 4 and St. 7 were also $+11.0 \%$ and below. The 
concentration of sulfate in a freshwater sample from St. 10 was quite low (sampling date: 21 Apr. 2001), and the $\delta^{34} \mathrm{~S}$ value was $+2.2 \%$, which is close to that of the crustal average. Sulfate concentrations in brackish water samples were highly variable in range from 3.9 to $21.5 \mathrm{mM}$. $\delta^{34} \mathrm{~S}$ values of sulfate in the brackish water samples collected at St. 4 on different dates and at different tide periods varied, ranging from +18.5 to $+20.5 \%$, and were much higher than that of inflowing freshwater to the Kitakami River estuary.

The habitat of $C$. japonica at St. 4 consisted of well-sorted sands. Size fractions of diameters of 0.5 to 0.212 and 0.5 to $1.0 \mathrm{~mm}$ predominated ( $44 \%$ and $54 \%$, respectively). The chemical and stable isotopic characteristics are shown in Table 2 (put Table 2 here). Ample sulfide-sulfur was obtained from black sandy sediments, whereas no sulfide was detected in brown-colored sand sediments. The isotopic values of sulfide-sulfur tended to be higher in May and June than those during September-November and February.

Sulfate concentration in the pore waters of the sediment tended to be higher in samples collected from St. 4, close to the river mouth (9.7-15.8 mM; Table 2), than in samples from the upstream St. 7 (2.6-5.2 mM). Higher $\delta^{34} \mathrm{~S}$ values of the sulfate in pore water $(+22.4$ to $+26.3 \%)$ from black sand sediments indicated that a bacterial reduction of seawater sulfate $\left(\delta^{34} \mathrm{~S}=+21.0 \%\right.$ ) was taking place, although an unusually high sulfate $\delta^{34} \mathrm{~S}$ value of $+27.5 \%$ was observed for pore-water sulfate in the brown sand at St. 7. The reason for this is unclear

\subsection{Fatty acid composition}

The fatty acid compositions of two samples of $C$. japonica are shown in Table 3 (put Table 3 here). Saturated and straight-chain C16 and C18 fatty acids were major components of the clam, while a substantial amount of monoenoic and methyl-branched fatty acids was detected. Saturated and straight long-chain acids $\geq$ C24) could not be detected. Unique fatty acids (i.e., iso 17:0 and anteiso 17:0 acids), both characteristic of 
sulfate-reducing bacteria, were observed. The predominance of the palmitoleic and vaccenic acids, 18:1 $\omega 7$ in $C$. japonica, may be related to their feeding on sulfur-oxidizing bacteria. PUFAs such as 20:5 and 22:6, which are typical biomarkers of phytoplankton, such as diatoms and algae, were only detected at trace levels from the sample taken from St. 4, although the sample from St. 7 contained small amounts of these PUFAs. Long-chain acids $(\geq \mathrm{C} 24)$ with an even carbon number were absent from the soft bodies of $C$. japonica.

\section{Discussion}

The brackish bivalve Corbicula japonica is the most abundant macrobenthic species in the Kitakami River estuary (Matsumasa et al., 2004). The density of $C$. japonica was higher in sandy sediments than in clayey and silty sediments, as has also been documented for Lake Shinji (Nakamura et al., 1988). In this brackish lake, Nakamura et al. (1988) and Yamamuro (1995) estimated that the major food source of the clam would be derived from phytoplankton that grew under oxidative conditions. However, analyses of stable carbon and nitrogen isotopic compositions have been used to suggest that clams in the river feed on marine and terrigenous POM (Doi et al., 2005). If $C$. japonica also feeds on phytoplankton (i.e., marine POM) in the Kitakami River estuary, we could expect that the resultant $\delta^{34} \mathrm{~S}$ values of the soft bodies would be around $+15 \%$ or higher. Common phytoplankton incorporate sulfate from the water column for their major sulfur nutrition (Yamanaka et al., 2003) and the majority of sulfate in estuarine ecosystems could be derived from the sea $\left(\delta^{34} \mathrm{~S}\right.$ values of the river water sulfate are close to $+21 \%$; see Table 1 ). However, the low sulfur isotopic signatures (ca. +2 to $+11 \%$ ) from the soft bodies of the clam in the Kitakami River estuary (Table 1) indicated that its major nutrition was derived from terrigenous organic matter, for which the $\delta^{34} \mathrm{~S}$ value is close to $0 \%$ (Trust and Fry, 1992), and/or a bacterial biomass, particularly SRB, which are associated with the occurrence of ${ }^{34} \mathrm{~S}$-depleted AVS in 
substrate sediments (Table 2). The contribution of such ${ }^{34} \mathrm{~S}$-depleted food sources tended to become more significant upstream (Table 1). Such bacteria are commonly found in sediments, and the low stable isotopic signatures of the sediment sulfides, together with the high values of associated pore-water sulfates (Table 2), suggested the bacterial cycling of sulfur between the brown oxidative and the black reductive sand layers, although the oxidative sediment prevails in $C$. japonica habitats.

Fatty acids in the soft body parts of $C$. japonica were also predominantly bacteria-derived acids such as monoenoic and branched acids (Table 3), confirming the importance of bacterial biomass in the nutrition of the clam. The predominance of bacteria was shown by an indicator $(18: 1 \omega 7 / 18: 1 \omega 9$ ratio $>1$; Pond et al., 1997) for C. japonica at the two different stations (Table 3). On the other hand, although diatoms should be characterized by a high 16:1 $\omega 7 / 16: 0$ ratio $\geq 1$ along with a high content of the 20:5 acid (Ackman et al., 1968), the ratios of our $C$. japonica samples were only 0.1 , and the $20: 5$ acid contents were very low ( $\leq 1.3 \%)$. In some cases, other plankton (i.e., some algae, fungi, and protozoa) are major prey for filter-feeding bivalves (Sargent, 1976), and PUFAs are considered to be indicators of planktonic-diet origins (Erwin, 1973; Sargent et al., 1987; Kayama et al., 1989; Zhukova and Kharlamenko, 1999). The C. japonica sample collected from St. 4 contained small amounts of PUFAs (1.8\%), although that from St. 7 exhibited detectable amounts of PUFAs (9.6\%). Therefore, based on the above fatty-acid compositions, bacteria, particularly the sulfate-reducing and sulfur-oxidizing bacteria associated with the sulfur cycle in the sediments, are the plausible major dietary sources for $C$. japonica in the Kitakami River estuary. Although the contribution of planktonic diets, characterized by PUFAs, may not be negligible at the upstream St. 7, the contribution of diatoms would be relatively small in this estuary, with its extensive reed marsh. This result may not exclude the direct assimilation of terrigenous organic matter using cellulase and hemicellulase, although the indirect assimilation of such organic matter via heterotrophic bacteria is the most plausible suggestion, as proposed by McLeod and Wing (2009). 
Mentioned above, our results suggest importance of bacterial biomass especially sulfate-reducing and sulfur-oxidizing bacteria as food source for $C$. japonica. SRB are typical obligate anaerobes. It is difficult for C. japonica to access SRB in sediment via filter feeding. However, Jørgensen (1977) demonstrated that sulfate reduction occurred in the anaerobic microniches of oxic coastal surface sediments. Fukui and Takii (1990) also found that survival of particle-associated SRB was higher than that of free-living SRB in oxic surface sediment of a seawater lake. It implies that $C$. japonica possibly feed SRB in resuspension particles in the bottom river water.

In addition to a wide distribution of SRB, ability of pedal feeding has been reported in $C$. fluminea (Reid et al., 1992). It proposes that the bivalve extend their foot down into substrate sediment, then ciliary currents on both sides of the foot conduct particles dorsally into the mantle cavity. It also suggests that the bivalve accumulates detritus in an anterior position just below the marginal gill food groves from pedal feeding during locomotion. C. japonica specimens used this study have been often observed around the reductive sandy layers where ample sulfides are detected as shown in Table 2. Therefore, it is plausible that the bivalves feed on microbes in the substrate sediment using their feet.

On the other hand, many types of sulfur-oxidizing bacteria can grow autotrophically using hydrogen sulfide as electron donor (e.g., Howarth and Teal, 1979). Chemoautotrophic sulfur-oxidizing bacteria generally have significant low $\delta^{13} \mathrm{C}$ values ( $-35 \pm 5 \%$; e.g., Ruby et al., 1987) during carbon fixation used Calvin cycle. If contribution of chemoautotrophic product can not be negligible, $\delta^{13} \mathrm{C}$ values of $C$. japonica should be drawn down. However, such trend is not appeared in the reported $\delta^{13} \mathrm{C}$ values of $C$. japonica in the Kitakami River estuary (Doi et al., 2005). In addition to chemoautotrophy, the genera Beggiatoa and Thioploca, which are major mat-forming sulfur-oxidizing bacteria and widespread in estuarine, continental shelf, deep-sea hydrothermal vent, and cold-seep environments, can grow heterotrophically, and facultatively or 
mixotrophically (e.g., Zhang et al., 2005). Therefore, isotopic compositions of those bacteria are not always so depleted in ${ }^{13} \mathrm{C}$ and sometimes reflect that of ambient dissolved organic substrates (Zhang et al., 2005). It suggests that carbon isotopic signature solely is not sufficient for evaluating contribution of sulfur-oxidizing bacteria as food source.

In temperate estuaries, large areas of the intertidal zone are often covered by dense stands of marsh plants (e.g., P. australis), and the benthic microalgae living on the sediment surface (e.g., diatoms) become less abundant because shading by the marsh plants reduces light intensity and thereby decreases algal productivity (Wainright et al., 2000). Using carbon and nitrogen stable isotope analyses for $C$. japonica in the Kitakami River estuary, Doi et al. (2005) reported that this nonselective filter feeder was using a POM that differed in composition along the river. Our results of fatty acid composition analysis, together with those of stable sulfur isotope analysis, also indicate that the diet of $C$. japonica changes spatially and that diatoms would be less important as food sources for this filter feeder in the Kitakami River estuary, with its dense stands of marsh plants.

In conclusion, our results from stable sulfur isotope and fatty acid analyses confirm that the bivalve $C$. japonica feeds on bacteria as well as on terrigenous organic matter and plankton in the Kitakami River estuary. Although diatoms are important as the major food for this species in lakes and lagoons, the contribution of diatom production and of the direct assimilation of terrigenous organic matter would be smaller than that of the heterotrophic bacterial biomass belonging to the thiobios in the Kitakami River estuary, with its extensive reed marsh. Such a trend is more significant toward upstream communities relative to those downstream around the river mouth. Since the densities of diatoms are usually lower in rivers than in lakes and lagoons, the stable sulfur isotope ratios and fatty acid compositions of $C$. japonica may reflect major sources of production and patterns in material flow. Hence, dietary studies on nonselective filter feeders, including C. japonica, will shed light on 
the differences in function between semi-closed ecosystems (e.g., lakes and lagoons) and relatively open estuarine ecosystems, as well as on the ecological roles of individual species.

\section{Acknowledgments}

The sulfur isotopic analysis was conducted at the Institute of Study for the Earth's Interior, Okayama University, as a joint research program. We are grateful to Professor Minoru Kusakabe for providing laboratory facilities. We also thank Mr. N. Satoh, Mr. S. Kumagai, and Mr. A. Kumagai for their extensive help with fieldwork and in stimulating discussion. We are also grateful to Prof. J. Hobbs of Iwate Medical University for his comments and assistance in improving the English in this manuscript. We appreciate the valuable comments given by two anonymous reviewers and editorial handling by Dr. Bianchi, Editor of this journal. This work is supported in part by the River Environmental Fund in charge of the Foundation of River and Watershed Environment Management, Japan, and by a Grant-in-Aid for Scientific Research (B) from the Japan Society for the Promotion of Science (No. 14380262). 


\section{References}

Ackman, R.G., Tocher, C.S., McLachlan J., 1968. Marine phytoplankter fatty acids. Journal of the Fisheries Research Board of Canada 25, 1603-1620.

Doi, H., Matsumasa, M., Toya, T., Satoh, N., Mizota, C., Maki, Y., Kikuchi, E., 2005. Spatial shifts in food sources for macrozoobenthos in an estuarine ecosystem: carbon and nitrogen stable isotope analyses. Estuary, Coastal and Shelf Sciences 64, 316-322.

Erwin, J.A., 1973. Comparative biochemistry of fatty acids in eukaryotic microorganisms. In: Erwin, J.A. (Ed.), Lipids and Biomembranes of Eukaryotic Microorganisms. Academic Press, NY, pp. 42-143.

Findlay, R.H., Trxler, M.B., Guckert, J.B., White, D.C., 1990. Laboratory study of disturbance in marine sediments: response of a microbial community. Marine Ecology Progress Series 62, 121-133.

Fukui, M., Takii, S., 1990. Survival of sulfate-reducing bacteria in oxic surface sediment of a seawater lake. FEMS Microbiology Ecology 73, 317-322.

Harvey, H.R., Eglinton, G., O'Hara, S.C.M., Corner, E.D.S., 1987. Biotransformation and assimilation of dietary lipids by Calanus feeding on a dinoflagellate. Geochimica et Cosmochimica Acta 51, 3031-3040.

Howarth, R.W., Teal, J.M., 1979. Energy flow in a salt marsh ecosystem: the role of reduced inorganic sulfur compounds. American Naturalist 116, 862-872.

Jørgensen, B.B., 1977. Bacterial sulfate reduction within reduced microniches of oxidized marine sediments. Marine Biology 41, 7-17.

Kasai, A., Nakata, A., 2005. Utilization of terrestrial organic matter by the bivalve Corbicula japonica estimated from stable isotope analysis. Fisheries Science 71, 151-158.

Kayama, M., Araki, S., Sato, S., 1989. Lipids of marine plants. In Ackman, R.G. (Ed.) Marine Biogenic Lipids, 
Fat and Oils, Vol. 2. CRC Press, Boca Raton, FL, pp. 3-48.

Kharlamenko, V.I., Kiyashko, S.I., Imbs, A.B., Vyshkvartzev, D.I., 2001. Identification of food sources of invertebrates from the seagrass Zostera marina community using carbon and sulfur stable isotope ratio and fatty acid analyses. Marine Ecology Progress Series 220, 103-117.

Matsumasa, M., Doi, H., Toya, T., Mizota, C., Maki, Y., Kikuchi, E., 2004. Spatial arrangement of macrozoobenthos in the Kitakami River estuary: an implication for management of estuarine ecosystems. In Maki, Y. (Ed.) Construction of grand design for local environmental associated with the reed field of the Kitakami River estuary, Iwate University, Morioka, pp 17-30.

McLeod, R.J., Wing, S.R., 2007. Hagfish in the New Zealand fjords are supported by chemoautotrophy of forest carbon. Ecology 88, 809-816.

McLeod, R.J., Wing, S.R., 2009. Strong pathways for incorporation of terrestrially derived organic matter into benthic communities. Estuarine, Coastal and Shelf Science 82, 645-653.

McLusky, D.S., 1989. The Estuarine Ecosystem. 2nd ed. Chapman \& Hall, New York, 215 pp.

Meziane, T., Tsuchiya, M., 2000. Fatty acids as tracers of organic matter in the sediment and food web of a mangrove/intertidal flat ecosystem, Okinawa, Japan. Marine Ecology Progress Series 200, 49-57.

Meziane T, Sanabe MC, Tsuchiya M (2002) Role of fiddler crabs of a subtropical intertidal flat on the fate of sedimentary fatty acids. Journal of Experimental Marine Biology and Ecology 270, 191-201.

Mizota, C., Shimoyama, S., Yamanaka, T., 1999. An isotopic characterization of sulfur uptake by benthic animals from Tsuyazaki Inlet, northern Kyushu, Japan. Benthos Research 54, 81-85.

Nakamura, M., Yamamuro, M., Ishikawa, M., Nishimura, H., 1988. Role of the bivalve Corbicula japonica in the nitrogen cycle in a mesohaline lagoon. Marine Biology 99, 369-374.

Pond, D.W., Segonzac, M., Bell, M.V., Dixon, D.R., Fallick, A.E., Sargent, J.R., 1997. Lipid and lipid carbon 
stable isotope composition of the hydrothermal vent shrimp Mirocaris fortunata: evidence for nutritional dependence on photosynthetically fixed carbon. Marine Ecology Progress Series 157, 221-231.

Rees, C.E., Jenkins, W.J., Monster, J., 1978. The sulphur isotopic composition of ocean water sulphate. Geochimica et Cosmochimica Acta 42, 377-381.

Reid, R.G.B., McMahon, R.F., Foighil, D.Ó., Finnigan, R., 1992. Anterior inhalant currents and pedal feeding in bivalves. The Veliger 35, 93-104.

Ruby, E.G., Jannasch, H.W., Deuser, W.G., 1987. Fractionation of stable carbon isotopes during chemoautotrophic growth of sulfur-oxidizing bacteria. Applied and Environmental Microbiology 53, 1940-1943.

Sakamoto, K., Toyohara, H., 2009a. A comparative study of cellulase and hemicellulase activities of brackish water clam Corbicula japonica with those of other marine Veneroida bivalves. The Journal of Experimental Biology 212, 2812-2818.

Sakamoto, K., Toyohara, H., 2009b. Putative endogenous xylanase from brackish-water clam Corbicula japonica. Comparative Biochemistry and Physiology, Part B 154, 85-92.

Sargent, J.R., 1976. The structure, function, and metabolism of lipids in marine organisms. In Malins, D.C., Sargent, J.R. (Eds.), Biochemical and Biophysical Perspectives in Marine Biology. Vol. 3. Academic Press, NY, pp. 149-212.

Sargent, J.R., Parkes, R.J., Mueller-Harvey, I., Henderson, R.J., 1987. Lipid biomarkers in marine ecology. In Sleigh, M. (Ed.), Microbes in the Sea. Ellis Horwood, Chichester, pp. 119-138.

Trust, B.A., Fry, B., 1992. Stable sulphur isotopes in plants: a review. Plant, Cell atid Environment 15, $1105-1110$.

Wainright, S.C., Weinstein, M.P., Able, K.W., Currin, C.A., 2000. Relative importance of benthic microalgae, 
phytoplankton and the detritus of smooth cordgrass Spartina alterniflora and the common reed Phragmites australis to brackish-marsh food webs. Marine Ecology Progress Series 200, 77-91.

Yamamuro, M., 1995. Eutrophication control by utilizing the characteristics of brackish ecosystems. Bulletin of the Society of Sea Water Science, Japan, 49, 129-135 (in Japanese).

Yamanaka, T., Murae, T., Chiba, H., 1999. Isotopic fractionation of sulfur in micro zones of tidal flat sediments. Geochemical Journal 33, 89-99.

Yamanaka, T., Shimoyama, S., Mizota, C., 2000. An evaluation of source sulfur in soft tissues of marine and freshwater benthic animals from Japan using stable isotope analysis. Benthos Research 55, 17-22.

Yamanaka, T., Mizota, C., 2001. Sulfur nutrition of gastropods and bivalves relevant to the mangrove forests: a case study from central Sumatra, Indonesia. VENUS 60, 71-78.

Yamanaka, T., Mizota, C., Shimoyama, S. (2003) Sulfur isotopic variations in soft tissues of five benthic animals from the reductive, tidal-flat sediments in northern Kyushu, Japan. Marine Biology 142, 327-331.

Yanagisawa, F., Sakai, H., 1983. Thermal decomposition of barium sulfate-vanadium pentaoxide-silica glass mixtures for preparation of sulfur dioxide in sulfur isotope ratio measurements. Analytical Chemistry 55, 985-987.

Zhang, C.L., Huang, Z.Y., Cantu, J., Pancost, R.D., Brigmon, R.L., Lyons, T.W., Sassen, R., 2005. Lipid biomarkers and carbon isotope signatures of a microbial (Beggiatoa) mat associated with gas hydrates in the Gulf of Mexico. Applied and Environmental Microbiology 71, 2106-2112.

Zhukova, N.V., Kharlamenko, V.I., 1999. Sources of essential fatty acids in the marine microbial loop. Aquatic Microbial Ecology 17, 153-157. 


\section{Captions}

Fig. 1. Sampling stations in the Kitakami River estuary.

\section{Table 1}

Concentration and sulfur isotopic composition of the soft-body parts of Corbicula japonica in the Kitakami River estuary.

Table 2

Chemical and stable isotopic characterization of sandy sediments in Corbicula japonica habitats.

Table 3

Fatty acid compositions (\% of total fatty acids) of Corbicula japonica. 


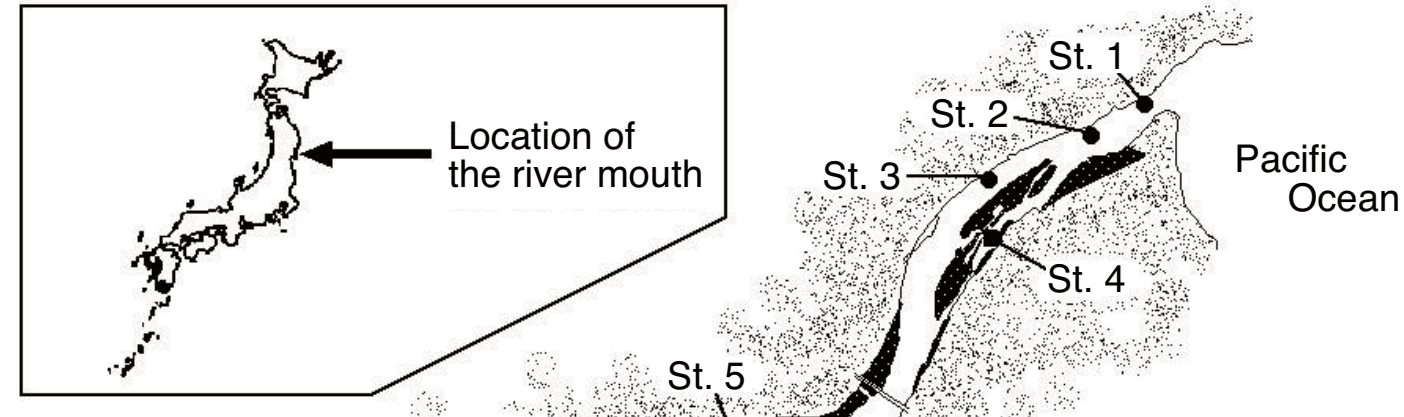

St. 10

St. 6

Kitakami Gateway

St. 7

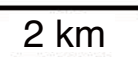

- Sampling stations

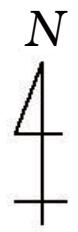

Reed marsh 
Table 1. Concentration and sulfur isotopic composition of soft-body part of Corbicula japonica in the Kitakami River estuary.

\begin{tabular}{|c|c|c|c|c|}
\hline \multirow{3}{*}{ Sample } & \multirow{3}{*}{ Date of collection } & \multirow{3}{*}{$\begin{array}{l}\text { Location of } \\
\text { sampling }^{\mathrm{b}}\end{array}$} & \multicolumn{2}{|r|}{ Sulfur } \\
\hline & & & \multirow{2}{*}{$\begin{array}{l}\text { Content } \\
\text { wt. } \%^{\mathrm{c}}\end{array}$} & \multirow{2}{*}{$\frac{\text { Isotope composition }}{\delta^{34} \mathrm{~S}(\% \mathrm{o})}$} \\
\hline & & & & \\
\hline Soft-body part of & August 10, 2001 & 1 & 0.60 & +9.1 \\
\hline \multirow[t]{9}{*}{ Corbicula japonica } & August 10, 2001 & 4 & 0.62 & +8.2 \\
\hline & August 10, 2001 & 5 & 0.62 & +7.3 \\
\hline & August 10, 2001 & 7 & 0.64 & +4.7 \\
\hline & August 10, 2001 & 8 & 0.65 & +3.4 \\
\hline & August 10, 2001 & 9 & 0.65 & +1.7 \\
\hline & December 15, 2001 & 4 & 0.51 & +10.1 \\
\hline & June 15,2003 & 7 & 0.57 & +3.9 \\
\hline & June $15,2003^{\mathrm{a}}$ & 7 & 0.53 & +4 \\
\hline & June 23, 2003 & 4 & 0.58 & +11 \\
\hline \multirow[t]{7}{*}{ Brackish river-water } & September 7, 2001 & 4 & $3.9^{\mathrm{d}}$ & +18.5 \\
\hline & November 23, 2001 & 4 & $13.8^{\mathrm{d}}$ & +19.6 \\
\hline & December 15,2001 & 2 & $21.5^{\mathrm{d}}$ & +20.4 \\
\hline & December 15,2001 & 4 & $18.8^{\mathrm{d}}$ & +20.4 \\
\hline & December 23, 2001 & 5 & $8.4^{\mathrm{d}}$ & +20.2 \\
\hline & December 15,2001 & 6 & $12.9^{\mathrm{d}}$ & +20.5 \\
\hline & February 11, 2004 & 4 & $11.3^{\mathrm{d}}$ & +20.5 \\
\hline Fresh water & April 21, 2001 & 10 & $0.09^{d}$ & +2.2 \\
\hline \multicolumn{5}{|c|}{ a Sample collected within black sediments. } \\
\hline \multicolumn{5}{|l|}{${ }^{\mathrm{b}}$ Refer Fig. 1.} \\
\hline${ }^{\mathrm{c}} 105^{\circ} \mathrm{C}$ dry-matter basis. & & & & \\
\hline
\end{tabular}


Table 2. Chemical and stable isotopic characterization of sandy sediments in Corbicula japonica habitats.

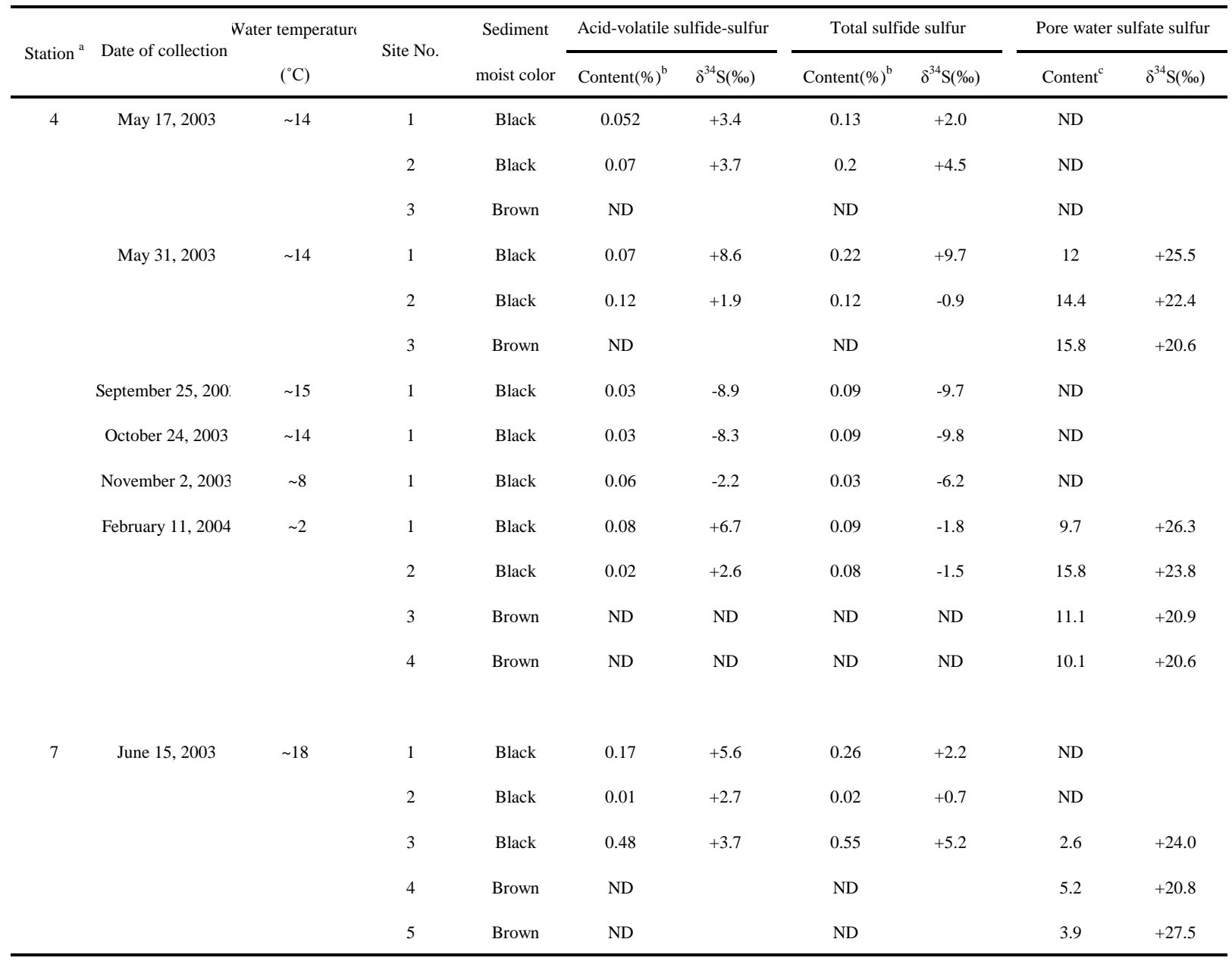

${ }^{\mathrm{a}}$ Refer Fig.1.

${ }^{\mathrm{b}} 105^{\circ} \mathrm{C}$ dry-matter basis.

${ }^{c}$ Concentration of dissolved sulfate as shown by $\mathrm{mM}$.

ND: Not detected 
Table 3. Fatty acid compositions (\% of total fatty acids) of Corbicula japonica sampled on 15 June, 2003.

\begin{tabular}{|c|c|c|c|c|}
\hline Fatty acid & St. 4 & St. 7 & Specific for & References \\
\hline 14:0 & 5.4 & 2.1 & & \\
\hline $\mathrm{i} 15: 0$ & 0.5 & 0.2 & Bacteria & Findlay et al., 1990; Kharlamenko et al., 2001 \\
\hline ai15: 0 & 0.2 & 0.1 & Bacteria & ditto \\
\hline $15: 0$ & 1.6 & 0.9 & & \\
\hline br16: 0 & 1 & 0.5 & & \\
\hline $16: 0$ & 43.8 & 31 & & \\
\hline $16: 1 \omega 7$ & 5.9 & 3.9 & Diatom & Erwin, 1973; Sargent et al., 1987 \\
\hline i1 $17: 0$ & 3.4 & 3.1 & Sulfate-reducing bacteria & Findlay et al., 1990; Kharlamenko et al., 2001 \\
\hline ai17: 0 & 1.5 & 1.5 & Sulfate-reducing bacteria & ditto \\
\hline $17: 0$ & 3.4 & 3.7 & & \\
\hline $17: 1 \omega 7$ & 0.1 & 0.8 & & \\
\hline $18: 0$ & 11.2 & 11.7 & & \\
\hline $18: 1 \omega 9 \mathrm{c}$ & 2.7 & 3.9 & & \\
\hline $18: 1 \omega 7 \mathrm{c}$ & 3.7 & 5.3 & Sulfur-oxidizing bacteria & Zhang et al., 2005 \\
\hline $18: 2 \omega 6 \mathrm{c}$ & 0.5 & 1.4 & & \\
\hline $18: 3 \omega 6$ & $\operatorname{tr}$ & 0.2 & & \\
\hline $18: 3 \omega 3$ & 0.9 & 1.4 & & \\
\hline $20: 0$ & 0.5 & 0.4 & & \\
\hline $20: 1 \omega 9 \mathrm{c}$ & 0.4 & 2.3 & & \\
\hline $20: 1 ?$ & 2.3 & 4.4 & & \\
\hline $20: 2 ?$ & 0.6 & 0.7 & & \\
\hline $20: 2 \omega 6$ & $\operatorname{tr}$ & 1.2 & & \\
\hline $20: 3 \omega 6$ & 0.3 & 0.2 & & \\
\hline $20: 3 \omega 3$ & 0.2 & 1.8 & & \\
\hline $20: 5 \omega 3$ & $\operatorname{tr}$ & 1.3 & Diatom & Erwin, 1973; Sargent et al., 1987 \\
\hline $21: 0$ & 0.7 & 0.7 & & \\
\hline $22: 0$ & 0.6 & 1.3 & & \\
\hline $22: 1 \omega 9$ & $\operatorname{tr}$ & 0.2 & & \\
\hline $22: 6 \omega 3$ & $\operatorname{tr}$ & 1.3 & Diatom & Erwin, 1973; Sargent et al., 1987 \\
\hline Total & 91.8 & 88.1 & & \\
\hline Saturated & 67.5 & 51.8 & & \\
\hline Monoenoic & 12.9 & 21.3 & & \\
\hline Branced & 5.6 & 4.9 & & \\
\hline PUFA & 1.8 & 9.6 & $\begin{array}{l}\text { Planktonic algae, fungi } \\
\text { protozoa }\end{array}$ & $\begin{array}{l}\text { and Erwin, 1973; Sargent et al., 1987; Kayama } \\
\text { et al., 1989; Zhukova and Kharlamenko, }\end{array}$ \\
\hline $\begin{array}{c}18: 1 \omega 7 / 18: 1 \omega \\
9\end{array}$ & 1.4 & 1.4 & Bacterial marker $(>1.0)$ & Pond et al., 1997 \\
\hline $16: 1 \omega 7 / 16: 0$ & 0.1 & 0.1 & Diatom marker $(>1.0)$ & Ackman et al., 1968 \\
\hline
\end{tabular}

